\title{
EXPLORING THE DETERMINANTS OF CUSTOMER SATISFACTION IN PAKISTAN AUTOMOTIVE INDUSTRY
}

\begin{abstract}
Ahmer Muslim
ABSTRACT

Customer satisfaction is a measure of how happy the customer is with the product or service offering of a business. Customers could be highly satisfied, satisfied, neutral, angry, or very angry. Similarly, service quality measures how best the service is meeting the customer's expectations. The customer satisfaction element is new to Pakistan automotive industry. The industry is still depending on selling cheap, low-quality products to the customer in order to increase market share. The purpose of this research is to create a customer satisfaction model for the automotive industry in Pakistan. The result at the end suggested that price, brand awareness, service quality, and Flexibility are the determinants of customer satisfaction for this industry. This research will open the way to expand the growth of industries and allow new competitors to enter the market with quality products.
\end{abstract}

Keywords: Customer Satisfaction; Customer's Expectations; Service Quality; Brand Awareness; Automotive Industry.

\section{INTRODUCTION}

Automotive Industry in Pakistan is still facing issues in correctly deploying marketing and customer satisfaction techniques to their operations. In Pakistan, the established automotive manufacturers have not faced any real competition for a sustained period, so, it can be said that the urge to identify factors involving or that can lead businesses to achieve customer satisfaction is quite unknown.

The automotive industry of Pakistan is very keen to produce vehicles with the lowest possible prices and do not let any other competitor delve in. The actual problem of the study here is to explore the key components that can help in achieving customer satisfaction, which can later turn into customer loyalty (Ali, Hussain, Konar, \& Jeon, 2017; Duy, \& Hoang, 2017). It will help both, manufacturer, and the customer, to achieve the value of product and service, rather 
than just buying cheap, low quality, and me-too sort of products (Guajardo, Cohen, \& Netessine, 2016).

For years, customer satisfaction has long been considered the gateway to customer loyalty. The automotive industry worldwide and other industries in Pakistan are embracing the factors that can lead to customer satisfaction. The aim of this research is to find the key factors affecting customer satisfaction in the automotive industry of Pakistan. The established key determinants of customer satisfaction are functional quality, brand awareness, price, service quality, and flexibility (Amin, \& Isa, 2018). With this research, the idea is to get the answer to the following questions

- What is the presence of key determinants of customer satisfaction in the industry?

- What is the significance of certain determinants of customer satisfaction?

\section{OBJECTIVES OF THE STUDY}

The main objective of the study is to develop a model for customer satisfaction in the automotive industry of Pakistan. The literature review will later describe and explain the existence of determinants as a measure of customer satisfaction. Here the independent variables are service quality, flexibility, functional quality, price, and brand awareness; and the dependent variable is customer satisfaction. The aim is to conduct an exploratory analysis of these determinants. The measures of customer satisfaction are displayed in table 1 .

\begin{tabular}{|l|l|}
\hline P1 & Service quality is a determinant of customer satisfaction \\
\hline P2 & Price is also one of the determinants of customer satisfaction. \\
\hline P3 & Functional quality is also one of the determinants of customer satisfaction \\
\hline P4 & Brand awareness is also the determinant of customer satisfaction \\
\hline P5 & Flexibility is also the determinant of customer satisfaction \\
\hline
\end{tabular}

Table 1: Determinants of Customer Satisfaction

\section{JUSTIFICATION OF THE STUDY}

This study will help the companies in identifying the determinants that could help them have better customer satisfaction. Above all the study will beneficially raise the level of products and services by the auto industry and may lead to attracting more customers and more employees towards the industry. The study will have an effect on the thinking and preferences 
of top management of the industry to shift focus towards these elements from mere production and selling.

\section{SCOPE OF THE STUDY}

The scope of this study includes the automotive industry of Pakistan. The vendors, equipment and machineries manufacturers, and dealers are not included in the part of this study. In the automotive industry, the scope is expanded to passenger and commercial vehicles. The industry may include truck, cars, light transport van, motorcycles, rickshaws, buses, scooter, and cargo vans.

\section{LITERATURE REVIEW}

The customer satisfaction model and the study of its determinants are now gaining popularity amongst many young researchers. The reason behind this is the paradigm shift from production capabilities to customer-centric marketing. In Pakistan, the research has been conducted on very various basic accounts but not particularly for the automotive industry.

\section{Customer Satisfaction}

There are many studies about customer satisfaction and the measures of customer satisfaction, and it is termed as one of the most important factors in the firms' overall success (Phan, \& Nham, 2015), and the ability to attract more business. Different studies show different elements as the determinant of customer satisfaction, but many research studies have few components very common.

\section{Service Quality and Customer Satisfaction}

"Service quality is a customer's overall impression of the relative inferiority or superiority of the organization and its services" (Bitner, Hubbert 1994). Edvardsson, Thomson and Ovretveit (1994) assert that it is about meeting the expectation of the customers regarding the service provided. The car as an example is not a one visit purchase, there may be many pre-purchase interactions, many after-sales activities, and much payments-related information transfer. These activities require a high efficiency of the staff and employees of the company to corporate with customers and help them with their queries (Triatmanto, Nirwanto, \& Razak, 2016). In this regard, the service quality depends on five major determinants, namely they are 
responsiveness, reliability, tangibility, assurance, and empathy. "Perceived service quality leads to customer satisfaction" Cronin, Taylor (1992). There is a very significant relationship between service quality and customer satisfaction, however, any specific transaction that is high with service quality will leave the customer satisfied with that particular transaction.

\section{Price and Customer Satisfaction}

In reality, the price is the most valuable object that is given to the company by the customer in order to obtain the product or service (Chan, 2017). How customer perceive the price is important in terms of customer satisfaction (Amudha, Nigama, Anand, Manjupriya, \& Siju, 2018). In addition, the effect of price stability and price change is also considered important in terms of satisfaction. Also, price is considered one of the most dominant factors in achieving competitive advantage. It means if the stable, low, and better price strategies or simply prices are deployed by the company it leaves customer more satisfied.

\section{Functional Quality and Customer Satisfaction}

The functional quality is determined by how well the quality of service is delivered. Functional quality is often combined with technical quality to measure the complete effect, but when customer satisfaction is considered the functional quality is of prime importance. If the good billing detail of service from the workshop is provided to the customer then it will leave the customer more satisfied, and the trust level will go up.

\section{Brand Awareness and Customer Satisfaction}

Brand awareness is the ability to recall and recognize certain brand amongst many (Jalleh, Donovan, Giles-Corti, \& Holman, 2002). "when it comes to automotive brand building, quality of awareness is more important than quantity" (Skyword, 2014). In Particular, in the automotive industry, brands that are on top of the mind have a serious advantage in customer mind ever since he starts planning to make the purchase.

\section{Flexibility and Customer Satisfaction}

It is the command over intelligence and future need of the market and making your strategies and offerings flexible to it. Suppose the customer is planning a service of a car and he is unable to visit your workshop. What if suddenly the message pops up in his mobile phone of your new 
offer of free pickup and delivery of vehicle for service. It will certainly increase the satisfaction level of the customer. Flexibility is a major part of the strategy, it covers the areas like new markets, products, and even discount and sales strategies.

\section{RESEARCH MODEL}

Before making the measurement model with the help of the literature review, we explored the determinants of customer satisfaction. The theoretical framework established on literature review, defining the problem, and establishing questionnaire the following theoretical model is developed:

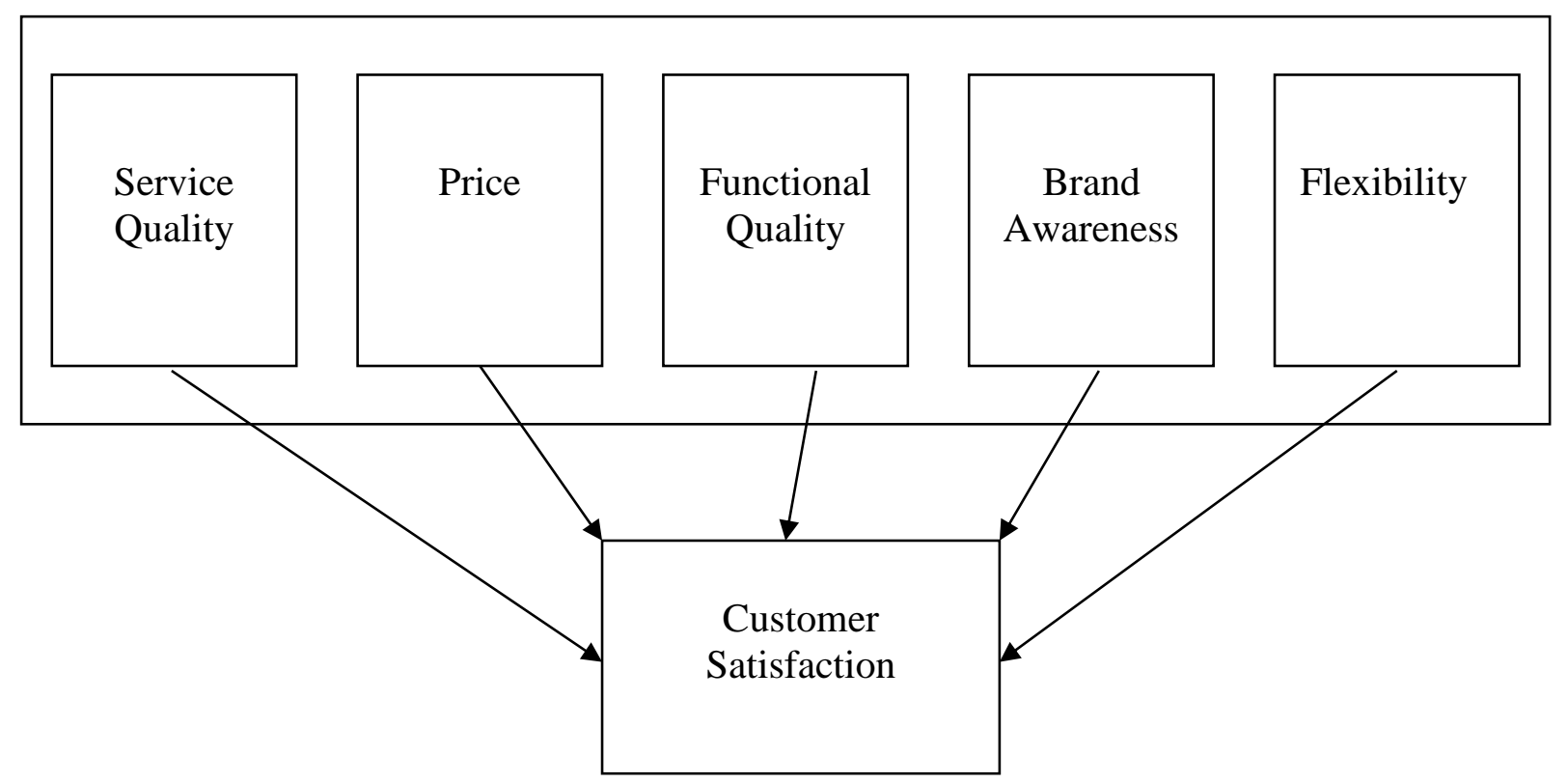

Figure 1: Theoretical Model

The five determinants chosen for customer satisfaction are price, service quality, functional quality, brand awareness, and flexibility.

\section{RESEARCH HYPOTHESIS}

H1: Service quality has a significant impact on customer satisfaction.

H2: Price has a significant impact on customer satisfaction.

H3: Functional quality has a significant impact on customer satisfaction.

H4: Brand awareness has a significant impact on customer satisfaction. 
H5: Flexibility has a significant impact on customer satisfaction.

\section{Research Variables and Instrument}

The following items in the questionnaire were selected after initial surveys and extensive literature review.

\begin{tabular}{|c|c|}
\hline Service Quality & $\begin{array}{l}\text { a. Staff is willing to answer any question or concern of the } \\
\text { customer. } \\
\text { b. Customers are informed after every transaction } \\
\text { c. Customers put more and more trust in service staff } \\
\text { d. Customers are always warmly welcomed by the receptionist }\end{array}$ \\
\hline Price & $\begin{array}{l}\text { a. Tariff rates provided by other networks/companies. } \\
\text { b. Perception of price fairness/unfairness } \\
\text { c. The price of the products are stable } \\
\text { d. The price of the products are affordable }\end{array}$ \\
\hline Functional Quality & $\begin{array}{l}\text { a. Accurate billing details } \\
\text { b. Good quality of customer services }\end{array}$ \\
\hline Brand Awareness & $\begin{array}{l}\text { a. The customer knows where to find the product. } \\
\text { b. When you think of a brand what comes to your mind? }\end{array}$ \\
\hline Flexibility & a. Ample choice of consumer promotion schemes \\
\hline Customer Satisfaction & $\begin{array}{l}\text { a. Overall Satisfaction with the company } \\
\text { b. The company always meets my expectation } \\
\text { c. Feel good using the company's product }\end{array}$ \\
\hline
\end{tabular}

\section{RESEARCH METHODOLOGY}

\section{Research Design}

The research is qualitative in nature but for data interpretation, both quantitative and qualitative approach is used. Based on the design of the research it is defined as exploratory research. The research is more of the inductive approach towards setting the general tentative hypothesis towards customer satisfaction in the automotive industry. The data collected is non-numerical 
data and the questionnaire is based on a five-point Likert scale. Point 1 for strongly agree and Point 5 for strongly disagree. The study also included in-depth interviews. The scope of the research is basic and is spread to the automotive industry of any genre of Pakistan, it may be 2,3 , or 4 wheel vehicle manufacturer. The type of investigation is correlational, as it is not necessary that every time stable price definitely make the customer satisfied. The study setting is non-contrived. The time horizon of the study is cross-sectional.

\section{Population and Sample}

The population of the study includes all Pakistan's national who have purchased any sort of vehicle either two-wheel, four-wheel, or three wheels, or even long trailer or bus in the last 5 years and using services of the OEM.

The sampling frame is the sales invoices that have the name of customers from different manufacturers. The sampling unit is one single individual. Stratified random sampling is used in such a manner that for every company there are selected 20 individual users of each automotive company. Thus, the sampling size is 20 multiplied by the number of automobile companies.

\section{Instrumentation}

Instruments used for the research are questionnaire and in-depth interviews. Since there are both interviews and questionnaire it can be said that we used the researcher- completed instrument and subject-completed instrument both. For the questionnaire, the established set of items are used and reference to the items are mentioned. Here the validity is measured using conformity factor analysis (Teo, 2011). The measurement model defines the reliability of the items. Here the independent variables are service quality, flexibility, functional quality, price, and brand awareness; and the dependent variable is customer satisfaction.

\section{Data Analysis Plan}

Thematic analysis is used, the face-to-face interview is conducted before the questionnaire filling. 


\section{RESULTS}

\section{Inferential Statistics}

\begin{tabular}{|l|c|c|c|}
\hline \multicolumn{1}{|c|}{ Hypothesis } & $\begin{array}{c}\text { Standardized } \\
\text { Path Coefficient }\end{array}$ & P-Value & Result \\
\hline $\begin{array}{l}\text { H1: Service quality has a significant } \\
\text { impact on customer satisfaction }\end{array}$ & 0.65 & 0.005 & Accepted \\
\hline $\begin{array}{l}\text { H2: Price has a significant impact on } \\
\text { customer satisfaction }\end{array}$ & 0.54 & 0.002 & Accepted \\
\hline $\begin{array}{l}\text { H3: Functional quality has a significant } \\
\text { impact on customer satisfaction }\end{array}$ & 0.21 & 0.617 & Rejected \\
\hline $\begin{array}{l}\text { H4: Brand awareness has a significant } \\
\text { impact on customer satisfaction }\end{array}$ & 0.42 & 0.041 & Accepted \\
\hline $\begin{array}{l}\text { H5: Flexibility has a significant impact } \\
\text { on customer satisfaction }\end{array}$ & 0.36 & 0.030 & Accepted \\
\hline
\end{tabular}

Table 2: Results

\section{Hypothesis Assessment Summary}

\begin{tabular}{|l|c|}
\hline \multicolumn{1}{|c|}{ Hypothesis } & Result \\
\hline H1: Service quality has a significant impact on customer satisfaction & Accepted \\
\hline H2: Price has a significant impact on customer satisfaction & Accepted \\
\hline H3: Functional quality has a significant impact on customer satisfaction & Rejected \\
\hline H4: Brand awareness has a significant impact on customer satisfaction & Accepted \\
\hline H5: Flexibility has a significant impact on customer satisfaction & Accepted \\
\hline
\end{tabular}

Table 3: Hypothesis Assessment Summary

\section{DISCUSSION}

From the above data analysis and research findings, we have derived the following research implications

- Functional quality is not significant when it relates to customer satisfaction in the automotive industry. 
- Service quality has the most significant relationship to customer satisfaction.

- Price, brand awareness, and flexibility has also a significant relationship with customer satisfaction.

\section{CONCLUSION}

This research examined factors affecting customer satisfaction, and we reach the result that price, brand awareness, flexibility, and service quality affects customer satisfaction. This study was intended to find the determinants of customer satisfaction that are applicable to the Pakistan automotive industry. The literature review played an important part in the identification of items, questionnaire, and research model for this research. Also, with the help of results, we can now say that functional quality is not of much interest when it comes to customer satisfaction. It is however necessary to expand the study to other industries and other customer satisfaction determinants. With this, we will in the future reach more conclusive evidence. 


\section{REFERENCES}

Ali, F., Hussain, K., Konar, R., \& Jeon, H. M. (2017). The effect of technical and functional quality on guests' perceived hotel service quality and satisfaction: A SEM-PLS analysis. Journal of Quality Assurance in Hospitality \& Tourism, 18(3), 354-378.

Amin, M., \& Isa, Z. (2008). An examination of the relationship between service quality perception and customer satisfaction. International Journal of Islamic and Middle Eastern Finance and Management.

Amudha, R., Nigama, K., Anand, J. S., Manjupriya, S., \& Siju, R. (2018). Assessing Service Quality in Automobile Sector. International Journal of Pure and Applied Mathematics, 119(7), 2613-2619.

Bitner, M. J., \& Hubbert, A. R. (1994). Encounter satisfaction versus overall satisfaction versus quality. Service quality: New directions in theory and practice, 34(2), 72-94.

Chakraborty, S., \& Sengupta, K. (2014). Structural equation modelling of determinants of customer satisfaction of mobile network providers: Case of Kolkata, India. IIMB Management Review, 26(4), 234-248.

Chan, M. (2017, October). How your pricing strategy affects customer satisfaction. Unleashed. Retrieved from: https://www.unleashedsoftware.com/blog/pricing-strategy-affects-customer$\underline{\text { satisfaction }}$

Duy, P. N. N., \& Hoang, T. M. (2017, March). Factors Affecting Customer Satisfaction and Customer Loyalty the Case of Binh Duong Ceramic Product. In Proceedings of NIDA International Business Conference 2017-Innovative Management: Bridging (p. 380).

Edvardsson, B., Thomasson, B., \& Ovretveit, J. (1994). Quality in service. Maidenhead.

Guajardo, J. A., Cohen, M. A., \& Netessine, S. (2016). Service competition and product quality in the US automobile industry. Management Science, 62(7), 1860-1877.

Jalleh, G., Donovan, R. J., Giles-Corti, B., \& Holman, C. D. A. J. (2002). Sponsorship: impact on brand awareness and brand attitudes. Social Marketing Quarterly, 8(1), 35-45. 
Phan, C., \& Nham, P. (2015). Impact of service quality on customer satisfaction of automated teller machine service: A case study of a private commercial joint stock bank in Vietnam. Business: Theory and Practice, 16, 280.

Skyword. (2014). Brand Awareness. Retrieved from: https://trackmaven.com/marketingdictionary/brand-awareness/

Swaddling, D. C., \& Miller, C. (2002). Don't measure customer satisfaction. Quality Progress, 35(5), 62-67.

Triatmanto, B., Nirwanto, N., \& Razak, I. (2016). The impact of product quality and price on customer satisfaction with the mediator of customer value. IISTE: Journal of Marketing and Consumer Research, 30, 59-68.

Xu, L. U., Blankson, C., \& Prybutok, V. (2017). Relative contributions of product quality and service quality in the automobile industry. Quality Management Journal, 24(1), 21-36. 